\title{
PENCANGKOKAN POLI (N-ISOPROPILAKRILAMIDA) PADA JARING RASCHEL POLIETILENA MENGGUNAKAN PLASMA LUCUTAN KORONA BERTEKANAN ATMOSFIR
}

POLY (N-ISOPROPYLACRYLAMIDE) GRAFTING ON POLYETHYLENE RASCHEL NET USING ATMOSPHERIC PRESSURE CORONA DISCHARGE PLASMA

\author{
Doni Primadi ${ }^{1,2}$, Noerati ${ }^{2}$, Mohamad Widodo*2 \\ ${ }^{1}$ Balai Besar Tekstil, Bandung, 40272, Indonesia \\ 2Politeknik STTT Bandung, Bandung, 40272, Indonesia \\ *Alamat e-mail penulis korespondensi: mwidodo@stttekstil.ac.id \\ Tanggal diterima: 31 Januari 2021; direvisi: 30 Maret 2021; \\ disetujui terbit: 17 April 2021
}

\begin{abstract}
ABSTRAK
Poli(N-isopropilakrilamida) (PNIPAAm) merupakan polimer responsif yang peka terhadap perubahan temperatur di sekitarnya dan telah banyak dipelajari untuk aplikasi tekstil cerdas. Pada studi ini, plasma lucutan korona bertekanan atmosfir telah digunakan untuk mencangkokkan PNIPAAm pada permukaan jaring polietilena. Pengamatan morfologi permukaan dengan SEM memberikan petunjuk awal pembentukan lapisan pada permukaan pita polietilena. Analisa kimia permukaan dengan FTIR mengkonfirmasi bahwa lapisan tersebut merupakan lapisan PNIPAAm yang telah berhasil dicangkokkan pada permukaan polietilena. Keberadaan PNIPAAm ditunjukkan dari kemunculan puncak-puncak serapan khas polimer tersebut pada frekuensi $1541 \mathrm{~cm}^{-1}$ dan $3428 \mathrm{~cm}^{-1}$ untuk regangan $\mathrm{NH}$ amida sekunder, $1639 \mathrm{~cm}^{-1}$ untuk regangan amida sekunder $\mathrm{C}=\mathrm{O}$, dan $2934 \mathrm{~cm}^{-1}$ untuk regangan asimetris $-\mathrm{CH}_{3}$. Puncak-puncak tersebut ditemukan pada semua spektra hasil pencangkokan yang belum maupun yang sudah dicuci dengan air ataupun detergen yang membuktikan bahwa NIPAAm telah berikatan kimia dan tercangkok dengan baik pada permukaan jaring polietilena. Hasil perhitungan penambahan berat pada sampel yang sudah dicuci menunjukkan jumlah pencangkokan NIPAAm bertambah sesuai dengan lamanya waktu iradiasi, yaitu 2,83\%, 4,82\% dan 5,37\% pada perlakuan plasma selama 5, 10 dan 15 menit. Semakin lama waktu iradiasi plasma semakin banyak radikal bebas yang terbentuk pada permukaan polietilena dan menjadi pusat-pusat reaksi sehingga semakin banyak pula PNIPAAm yang berikatan dan berhasil dicangkokkan.
\end{abstract}

Kata kunci: Jaring raschel polietilena, PNIPAAm, iradiasi plasma, polimerisasi cangkok dengan bantuan plasma

\section{ABSTRACT}

Poly(N-isopropilacrylamide) (PNIPAAm) is one of the most studied thermoresponsive polymers that can be used for smart textile applications. Its particular responsiveness to temperature change can be uti to make a smart water harvesting net that can 
capture water from air and release it autonomously. In this study, an atmospheric pressure corona discharge plasma was used to graft NIPAAm to the surface of polyethylene net. SEM observation revealed the presence of grafted PNIPAAm layer. Further, FTIR analysis showed the emergence of new peaks at the wavenumbers of $1541 \mathrm{~cm}^{-1}$ and $3428 \mathrm{~cm}^{-1}$ for the stretching $\mathrm{NH}$ in the secondary amide, $1639 \mathrm{~cm}^{-1}$ for the stretching vibration of $\mathrm{C}=\mathrm{O}$ in the secondary amide, and the asymmetric stretching of terminal groups of $-\mathrm{CH} 3$ at $2934 \mathrm{~cm}^{-1}$. The peaks remained in the spectra after washing with detergent, which proved that PNIPAAm has been successfully chemically grafted to the surface of polyethylene. The grafting yield increases with the irradiation time from $2.83 \%$ to $4.82 \%$ and $5.37 \%$ with the plasma treatment of 5, 10, and 15 minutes respectively. The longer the time of irradiation the more surface free radicals that were formed on the surface of polyethylene, hence more reaction sites for the grafting of PNIPAAm.

Key words: Polyethylene raschel net, PNIPAAm, plasma irradiation, plasma-assisted graft polymerization

\section{PENDAHULUAN}

Stimuli responsive polymers atau polimer peka rangsangan adalah sekelompok polimer yang memiliki kemampuan merespon kondisi lingkungan di sekitarnya. Bahan-bahan polimer ini dapat berubah bentuk, warna dan sifat-sifat fisik ataupun kimia lainnya akibat respon dari rangsangan eksternal yang dialami dari interaksi dengan kondisi lingkungan di sekitarnya seperti temperatur, $\mathrm{pH}$, cahaya dll ${ }^{1,2}$ sehingga polimer ini juga disebut sebagai 'polimer cerdas'. Respon dari polimer cerdas ini dapat digunakan untuk mengatur aktivitas di berbagai aplikasi yang diinginkan termasuk di bidang teknologi tekstil, khususnya pada wilayah tekstil teknik (technical textiles) dan tekstil cerdas (smart textiles).

Salah satu jenis polimer cerdas dan peka terhadap lingkungan adalah polimer termoresponsif. Polimer ini berubah sifatnya dari hidrofilik ke hidrofobik dan sebaliknya secara mandiri mengikuti suatu siklus perubahan temperatur tertentu melewati titik yang disebut sebagai low critical solution temperature (LCST) yang merupakan suatu sifat khusus pada polimer termoresponsif. Lower critical solution temperature (LCST) merupakan titik transisi perubahan fase polimer di dalam larutan. Pada temperatur di bawah titik LCST seluruh komponen senyawa polimer berada pada satu fasa dengan larutan dan dalam kondisi terlarut (Gambar 1). Sebaliknya, pada temperatur di atas titik LCST seluruh komponen senyawa polimer dalam larutan akan mengalami pemisahan fasa di mana polimer akan keluar dari fase larutan dan mengalami pemisahan menjadi tidak terlarut ${ }^{3}$. Titik LCST poli ( $\mathrm{N}$-isopropilakrilamida) (PNIPAAm) berada pada temperature $32^{\circ} \mathrm{C} 4,5$ dan dekat dengan temperatur tubuh sehingga banyak dipelajari pemanfaatannya untuk aplikasi yang berhubungan dengan fungsi fisiologis tubuh. Polimer ini berubah sifatnya dari hidrofobik pada saat temperatur di atas titik LCST menjadi hidrofilik di saat temperatur lingkungan turun hingga di bawah titik LCST ${ }^{4}$. 
(a)

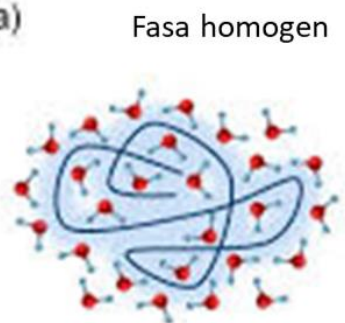

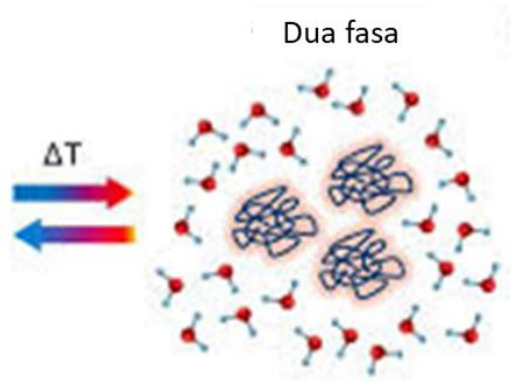

(b)

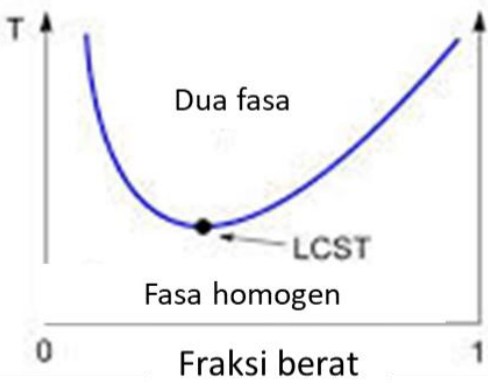

b. Diagram fasa polimer termoresponsif

Gambar 1. Diagram fasa dan perubahan konformasi serta kelarutan polimer termoresponsif akibat perubahan suhu melewati titik LCST-nya.

Salah satu pemanfaatan PNIPAAm pada bidang tekstil yang belakangan ini cukup mendapat perhatian adalah untuk memberikan sifat cerdas responsif pada aplikasi penangkapan air (water harvesting) ${ }^{4}$. Bahan yang biasa digunakan untuk penangkapan air dan telah banyak dipelajari antara lain terbuat dari jaring raschel polietilena 6,7. Jaring semacam ini banyak digunakan pada bidang pertanian untuk mengurangi intensitas matahari dan air hujan yang mengenai tanaman ${ }^{8}$ dan mudah diperoleh di Indonesia dengan harga yang relatif murah. Modifikasi permukaan bahan tekstil penangkap air, termasuk dengan polimer termoresponsif, telah terbukti mampu meningkatkan kemampuan penangkapan dan pengumpulan air menjadi lebih besar ${ }^{4,6}$. Pada studi yang dilakukan oleh Yang dkk. ${ }^{4}$, kain kapas dicangkokkan dengan NIPAAm melalui serangkaian prosedur kimia yang cukup panjang dan rumit serta memakan waktu lama yang dikenal sebagai surface-initiated atom transfer radical polymerization (SI-ATRP) atau polimerisasi radikal perpindahan atom pada permukaan. Kain kapas yang telah dicangkok dan dipolimerisasi dengan PNIPAAm memperlihatkan penangkapan dan penglepasan air secara mandiri mengikuti siklus perubahan temperatur di sekitar LCSTnya, yaitu pada temperatur $32{ }^{\circ} \mathrm{C}$.
Mekanisme penangkapan dan penglepasan air tersebut diduga dapat meningkatkan pengumpulan air dengan cara memaksimumkan penangkapan pada temperatur rendah yang mengandung lebih banyak uap air, sementara penglepasan dimaksimumkan pada temperatur yang lebih tinggi di mana kandungan uap air di udara pada umumnya lebih sedikit.

Selain dengan SI-ATRP yang relatif panjang dan rumit prosedurnya, polimerisasi cangkok pada permukaan bahan dapat dilakukan dengan iradiasi ultraviolet (UV), ozon dan plasma ${ }^{1}$. Dengan iradiasi UV dan plasma, permukaan bahan diaktivasi terlebih dulu untuk menghasilkan spesi aktif permukaan yang nantinya menjadi titik untuk inisiasi pencangkokan. Plasma telah banyak digunakan untuk polimerisasi cangkok, termasuk juga pencangkokan PNIPAAm pada permukaan polipropilena ${ }^{9}$, membran polietilena ${ }^{10}$ dan film nilon 6.6 , kapas serta polistirena ${ }^{1}$

Plasma adalah sebentuk energi radiasi hasil ionisasi parsial gas dan merupakan campuran berbagai macam spesi aktif yang terdiri dari elektron, radikal bebas, ion-ion positif dan negatif, atom dan molekul netral, serta foton. Interaksi antara unsur-unsur spesi aktif tersebut dengan permukaan bahan dapat menghasilkan kombinasi berbagai macam efek permukaan yang 
berguna seperti pembentukan radikal bebas dan gugus-gugus reaktif permukaan yang dapat dimanfaatkan untuk modifikasi kimia permukaan bahan melalui polimerisasi cangkok. Plasma lucutan korona merupakan salah satu jenis plasma yang paling banyak digunakan dan dijadikan sebagai bahan studi karena desainnya tergolong sederhana dan dapat menghasilkan plasma yang relatif stabil dengan mudah. Hingga sejauh ini belum ada studi yang mempelajari penggunaan plasma untuk polimerisasi cangkok PNIPAAm pada jaring raschel polietilena, terutama dalam konteks pemanfaatannya untuk bahan penangkap air dari udara.

Tujuan dari studi ini adalah mempelajari penggunaan plasma lucutan korona bertekanan atmosfir dengan elektroda berkonfigurasi multititik-bidang dalam proses polimerisasi cangkok PNIPAAm, khususnya pengaruh waktu iradiasi terhadap efisiensi pencangkokan.

\section{BAHAN DAN METODA \\ BAHAN DAN ALAT}

Bahan tekstil yang digunakan dalam penelitian ini adalah jaring raschel polietilen yang biasa digunakan pada sektor pertanian dan mudah ditemukan di Indonesia (Gambar 2). Jaring tersebut dibeli dari toko alat pertanian

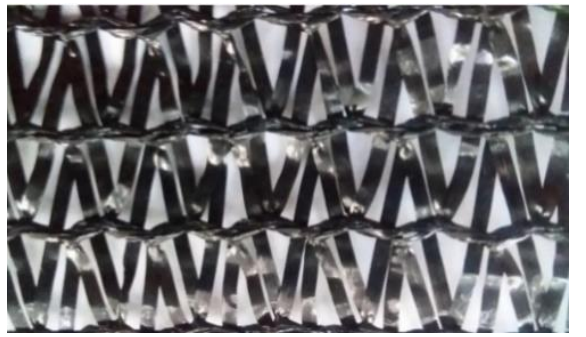

Gambar 2. Jaring raschel berbahan polietilena. lokal.<smiles>C=C(C)C(=O)NC(C)C</smiles>

Gambar 3. N-isopropilakrilamida Monomer N-isopropilakrilamida
(NIPAAm, BM = 113,16 $\mathrm{g} / \mathrm{mol}$ ) $97 \%$
diperoleh dari Sigma Aldrich Singapura
(CAS Number 2210-25-5) (Gambar 3),
sedangkan pelarut 2-propanol/lsopropil
alkohol 100\% untuk melarutkan
NIPAAm didapatkan dari PT.
Bratachem Bandung.

Peralatan yang digunakan untuk pencangkokan dan karaktrisasinya adalah sebagai berikut : (1) mesin plasma lucutan korona bertekanan atmosfir titik-bidang yang digunakan pada studi ini adalah hasil rancangan dan milik Balai Besar Tekstil (BBT) bekerja sama dengan Jurusan Kimia Tekstil Politeknik STTT Bandung dan Departemen Fisika Universitas Diponegoro (Gambar 4); mesin tersebut memiliki sumber daya bertegangan tinggi arus searah (DC) sebesar $20 \mathrm{kV}$ dan $100 \mathrm{~mA}$; (2) Scanning Electron Microscope (SEM) JEOL JSM-6510LV untuk analisa morfologi permukaan bahan; dan (3) Fourier Transform Infrared (FTIR) Spectroscope buatan Shimadzu model IRPrestige-21 untuk analisa sifat kimia permukaan dan gugus fungsional pada permukaan bahan. 


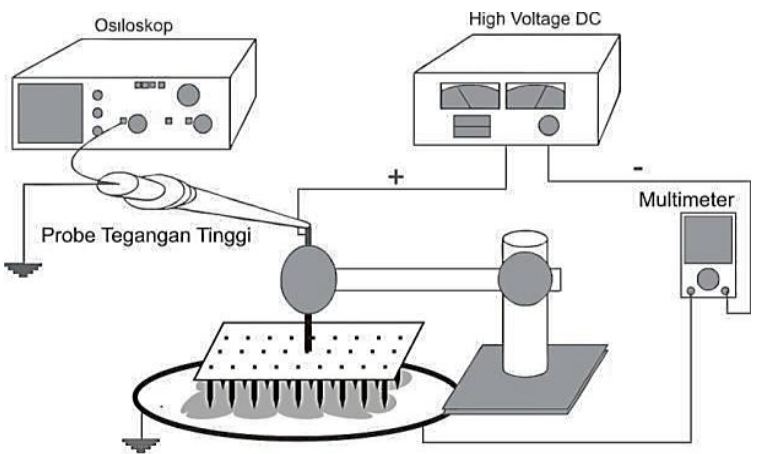

(a)

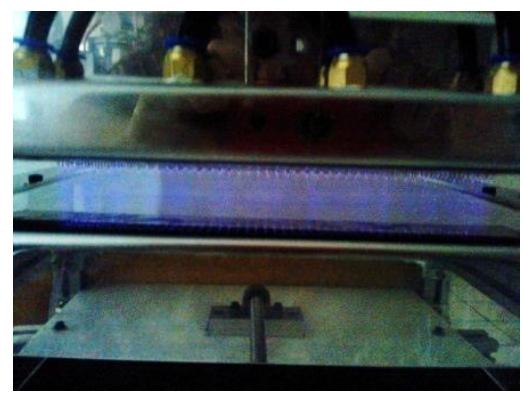

(c)

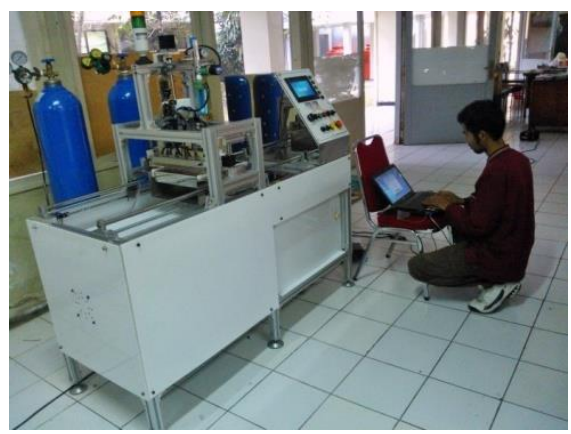

(b)

a) Skema rangkaian plasma lucutan korona memperlihatkan sumber daya DC dan elektroda titik-bidang.

b) Mesin plasma lucutan korona

c) Elektroda multititik-bidang memancarkan plasma

Gambar 4. Mesin plasma lucutan korona bertekanan atmosfir.

\section{METODE}

Jaring berukuran $2 \times 30 \mathrm{~cm}$ disiapkan sesuai dengan ukuran elektroda titik dan diletakkan pada elektroda bidang tepat di antara elektroda titik dan bidang. Kedua elektroda tersebut diatur berjarak tetap sejauh $20 \mathrm{~mm}$. Setelah melalui rangkaian percobaan pendahuluan dan pengaturan parameter, plasma stabil diperoleh pada tegangan sebesar $20 \mathrm{kV}$ dan arus sebesar $25 \mathrm{~mA}$. Iradiasi dilakukan selama 5,10 dan 15 menit di mana masing-masing variasi waktu terdiri dari 3 kelompok sampel, yaitu (1) tanpa pencucian, (2) dicuci dengan air mengalir, (3) dicuci dengan air mengalir dan penyabunan dengan deterjen. Semua sampel yang telah selesai diberi perlakuan plasma disimpan di dalam kantong plastik tertutup agar tidak mengalami kontak dengan udara dan hanya dikeluarkan tepat sebelum proses pencangkokan dengan NIPAAm.

Gambar 5 di bawah ini memperlihatkan diagram alir percobaan. Larutan NIPAAm $4 \quad M$ disiapkan dengan melarut-kan $5 \mathrm{~g}$ NIPAAm di dalam 11 $\mathrm{mL}$ isopropil alkohol 100\% pada temperatur kamar. Selanjutnya, sampel hasil proses plasma direndam di dalam larutan NIPAAm selama 5 menit. Sampel dikeluarkan dan dikeringkan perlahan di dalam oven pengering pada temperatur $60 \quad{ }^{\circ} \mathrm{C}$ selama 2 jam. Sebagian sampel disimpan tanpa pencucian (1), sebagian lainnya dicuci dengan air mengalir (2) dan diikuti dengan penyabunan (3) untuk menguji pembentukan ikatan dan pencangkokan. Masing-masing sampel tersebut dan sampel tanpa perlakuan selanjutnya ditimbang dan dicatat beratnya untuk menentukan kadar pencangkokan $(\mathrm{GY}=$ grafting yield) 
menggunakan perhitungan sebagai berikut:

$\mathrm{W}_{0}=$ berat kain tanpa perlakuan

$\mathrm{W}_{1}=$ berat setelah perlakuan

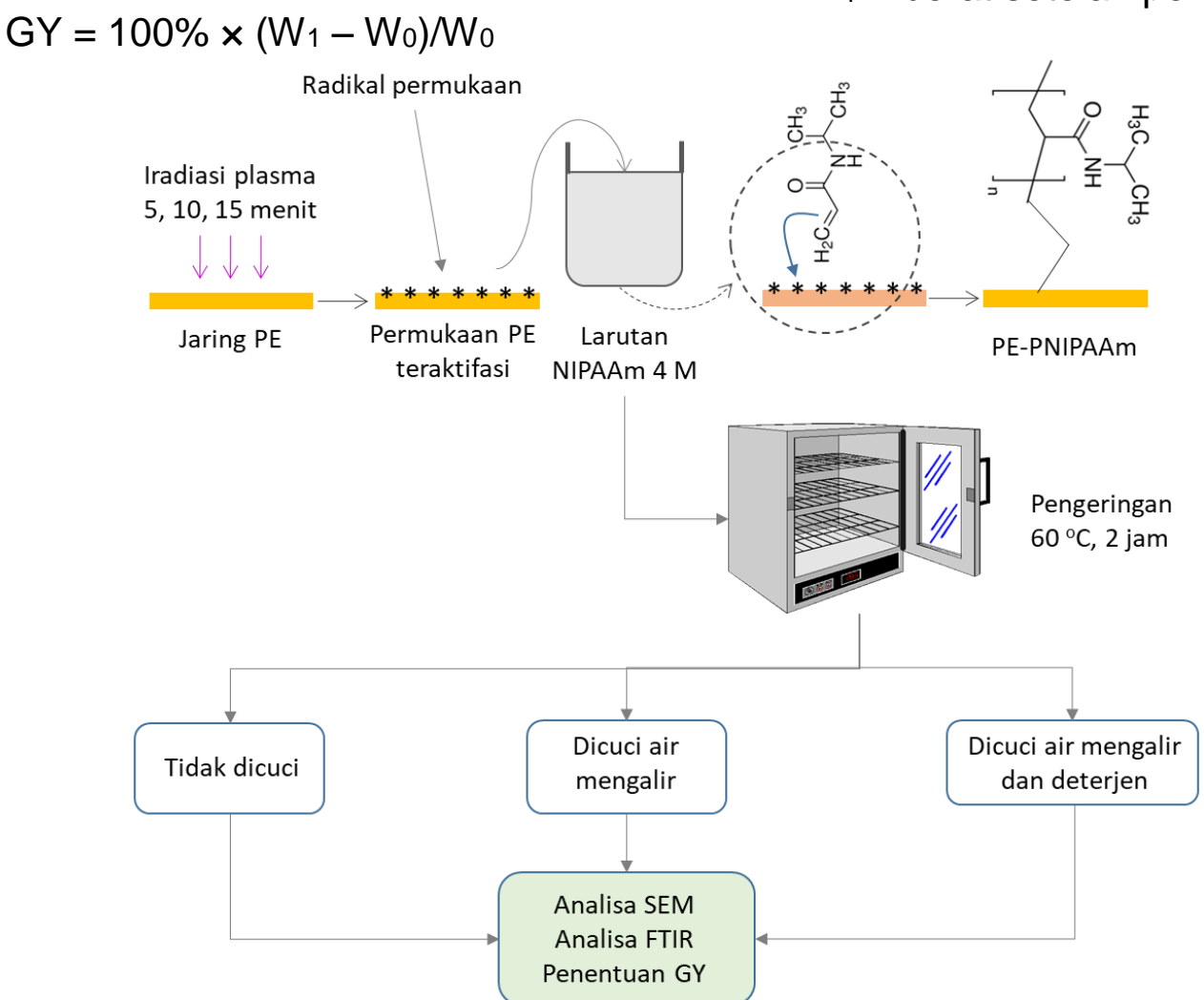

Gambar 5. Prosedur pelaksanaan percobaan pencangkokan PNIPAAm pada jaring raschel polietilena dengan menggunakan metode plasma-assisted graft polymerization atau polimerisasi cangkok dengan bantuan plasma.

Untuk mengkonfirmasi keberadaan PNIPAAm pada permukaan polietilena dan keberhasilan pencangkokan dilakukan analisa FTIR. Keberadaan puncakpuncak penciri gugus khas NIPAAm pada spektra hasil proses pada sampel tanpa dan dengan pencucian air maupun deterjen akan menjadi bukti keberadaan dan pencangkokan PNIPAAm pada permukaan polietilena.

\section{HASIL DAN DISKUSI \\ Modifikasi Kimia dan Fisik \\ Polietilena oleh Plasma}

Hasil pengujian titik leleh jaring polietilena menunjukkan temperatur $131^{\circ} \mathrm{C}$ yang menunjukkan bahwa jaring tersebut memang terbuat dari polietilena, sesuai dengan data yang dipublikasikan pada literatur ${ }^{11}$. Gambar 6 berikut di bawah ini memperlihatkan hasil pencitraan scanning electron microscope (SEM) dari permukaan polietilena hasil perlakuan plasma dengan waktu yang berbeda. Dapat diamati pada Gambar 6a-d bahwa iradiasi plasma telah mengubah morfologi permukaan polietilena. Permukaan polietilena yang telah diiradiasi selama 5 menit nampak mengalami pengelupasan, lalu pada waktu iradiasi selama 10 menit tampak adanya retakan-retakan. Pada jaring yang diiradiasi selama 15 menit terlihat permukaan serat juga mengalami retakan seperti jaring yang telah diiradiasi selama 10 menit, namun terlihat permukaannya lebih kasar jika dibandingkan dengan permukaan jaring yang telah diiradiasi selama 5 dan 10 menit. Semakin lama waktu iradiasi plasma maka permukaan serat menjadi 


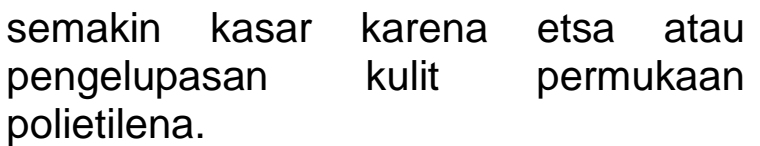

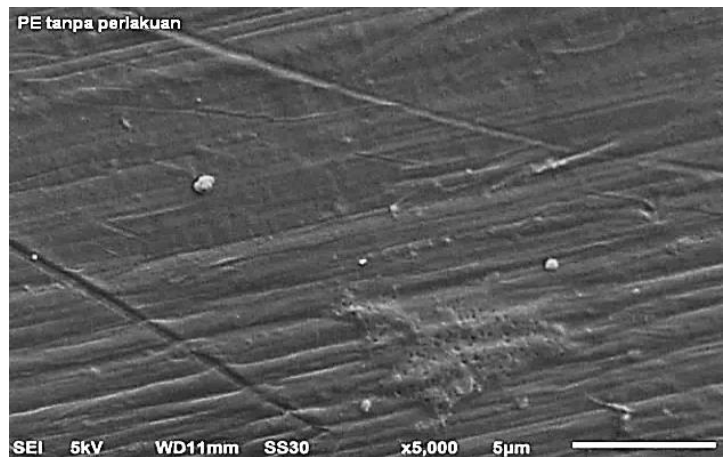

(a)

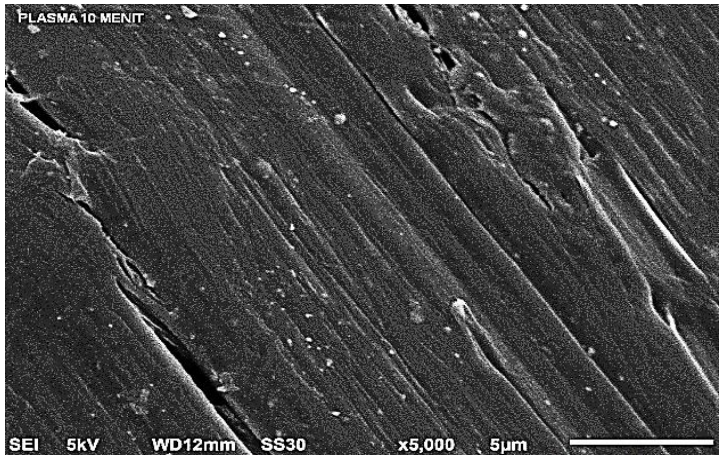

(c)

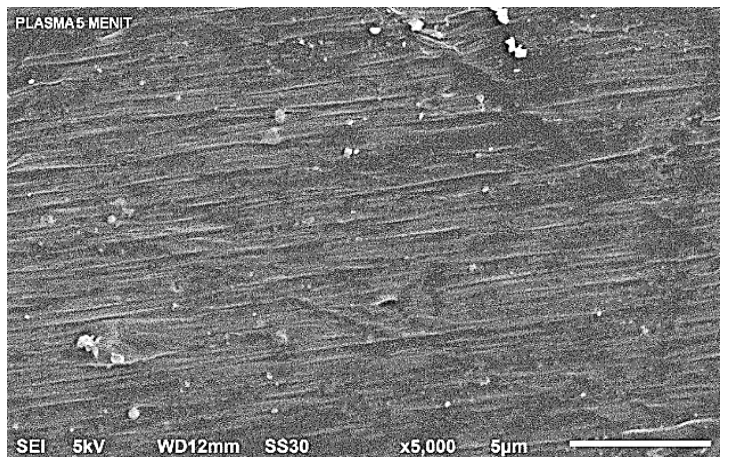

(b)

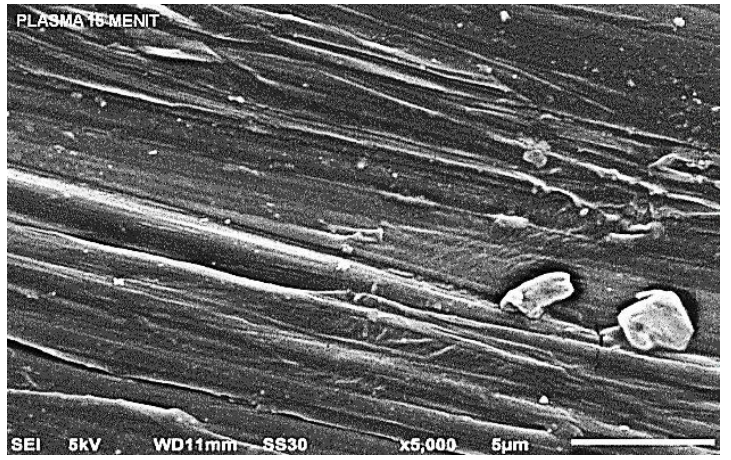

(d)

Gambar 6. Citra SEM permukaan polietilena sebelum (a) dan sesudah iradiasi plasma selama (b) 5 menit, (c) 10 menit dan (d) 15 menit.

Berbeda dengan serat kapas ataupun poliamida yang kaya dengan gugus reaktif di sepanjang rantai molekulnya, polietilena sama seperti poli(etilena tereftalat) tidak memiliki gugus-gugus reaktif yang mampu membentuk ikatan dengan senyawa lain, sehingga proses modifikasinya biasanya memerlukan prosedur kimia relatif yang panjang dan rumit. Plasma telah banyak dipelajari dan digunakan untuk memodifikasi permukaan bahan tekstil secara kimia dan fisik serta telah banyak dimanfaatkan untuk membantu pencangkokan senyawa ataupun polimerisasi cangkok, termasuk dengan NIPAAm. Plasma lucutan korona bertekanan atmosfir telah digunakan dalam studi ini untuk mengaktifkan permukaan polietilena melalui pembentukan gugus-gugus reaktif dan/atau radikal bebas permukaan sebagai titik pembentukan ikatan dan/atau inisiasi kopolimerisasi dengan NIPAAm. Pada perlakuan plasma dengan tekanan atmosfir tanpa asupan gas khusus terdapat unsur-unsur oksigen $(21 \%)$ dan nitrogen $(78 \%)$ yang terkandung di dalam udara bebas yang dapat berinteraksi bebas dengan plasma dan bahan, sehingga besar kemungkinan dapat menjadi sumber pembentukan gugus-gugus reaktif pembawa nitrogen dan oksigen pada permukaan serat.

Gambar 7 memperlihatkan spektra polietilena yang diperoleh dari pangkalan data komersial spektra FTIR sebagai referensi. Pada spektra tersebut terdapat puncak-puncak serapan khas polietilena pada frekuensi $2914 \mathrm{~cm}^{-1}, 2847 \mathrm{~cm}^{-1}, 1470 \mathrm{~cm}^{-1}$ dan 
$718 \mathrm{~cm}^{-1}$. Masing-masing puncak tersebut secara berturut-turut merupakan karakteristik dari regangan asimetrik dan simetrik $\mathrm{CH}_{2}$, bending asimetrik $\mathrm{CH}_{2}$, dan rocking $\mathrm{CH}_{2}$. Selanjutnya, pada Gambar 8 disajikan spektra polietilena dari jaring raschel sebelum dan sesudah iradiasi plasma dengan waktu pemajanan 5, 10 dan 15 menit. Spektra polietilena sebelum diiradiasi plasma (a) tidak menampakkan puncak-puncak serapan yang khas seperti spektra polietilena pada Gambar 7. Meski demikian, pengamatan lebih dekat dengan perbesaran pada daerah frekuensi 2800-3000 $\mathrm{cm}^{-1}$ menunjukkan adanya puncak serapan lemah pada $2994 \mathrm{~cm}^{-1}$ dan $2891 \mathrm{~cm}^{-1}$ yang cukup dekat dengan spektra polietilena standar pada Gambar 7. Meskipun tidak terlalu kentara, puncak serapan bending asimetrik dan rocking $\mathrm{CH}_{2}$ dapat diamati pada $1464 \mathrm{~cm}^{-1}$ dan $734 \mathrm{~cm}^{-1}$. Puncak-puncak mengkonfirmasi struktur kimia bahan jaring raschel dan masih dapat diamati dengan cukup jelas pada spektra sesudah iradiasi plasma (b, c, d). Pada ketiga spektra tersebut didapati puncak-puncak serapan baru pada $3428 \mathrm{~cm}^{-1}$ dan $1635 \mathrm{~cm}^{-1}$ yang menunjukkan stretching $\mathrm{O}-\mathrm{H}$ dan/atau $\mathrm{N}-\mathrm{H}$ serta bending $\mathrm{N}-\mathrm{H}$. Hal tersebut sesuai dengan dugaan sebelumnya mengenai kemungkinan interaksi dengan unsur-unsur $\mathrm{O}_{2}$ dan $\mathrm{N}_{2}$ di udara. Gugus-gugus hidrofilik $-\mathrm{OH}$ dan -NH tersebut memiliki peran penting dan dapat ikut membantu proses pencangkokan NIPAAm pada polietilena. Pada spektra (b) dan (d) didapati puncak serapan yang cukup menonjol namun tidak ditemui pada spektra (c), yaitu pada $2365 \mathrm{~cm}^{-1}$. Karena tidak konsisten teramati pada ketiga spektra, maka dalam konteks batasan studi ini puncak tersebut untuk sementara dapat diabaikan.

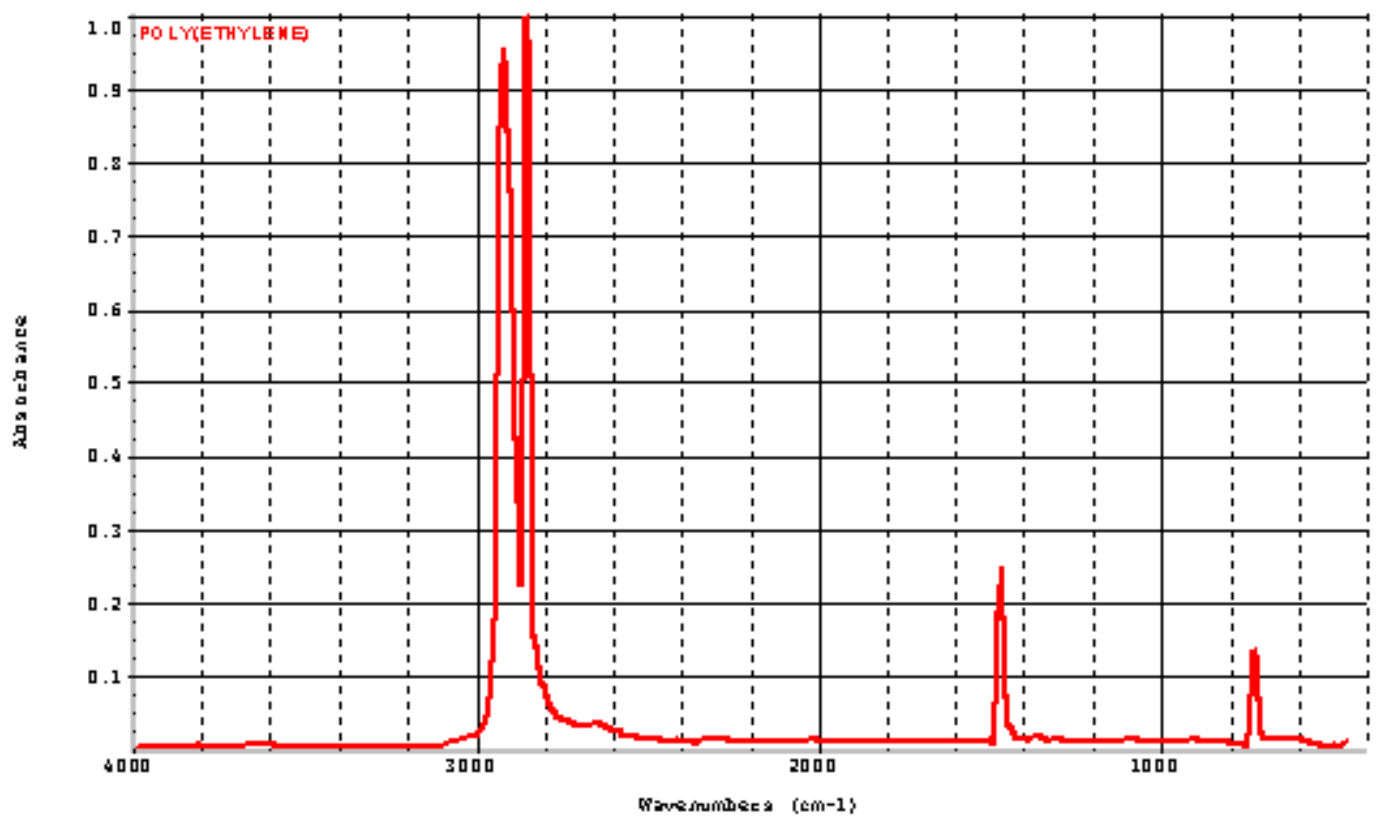

Gambar 7. Spektra polietilena dengan puncak-puncak serapan khasnya. (Sumber: http://www.ftir-polymers.com/soon.htm) 


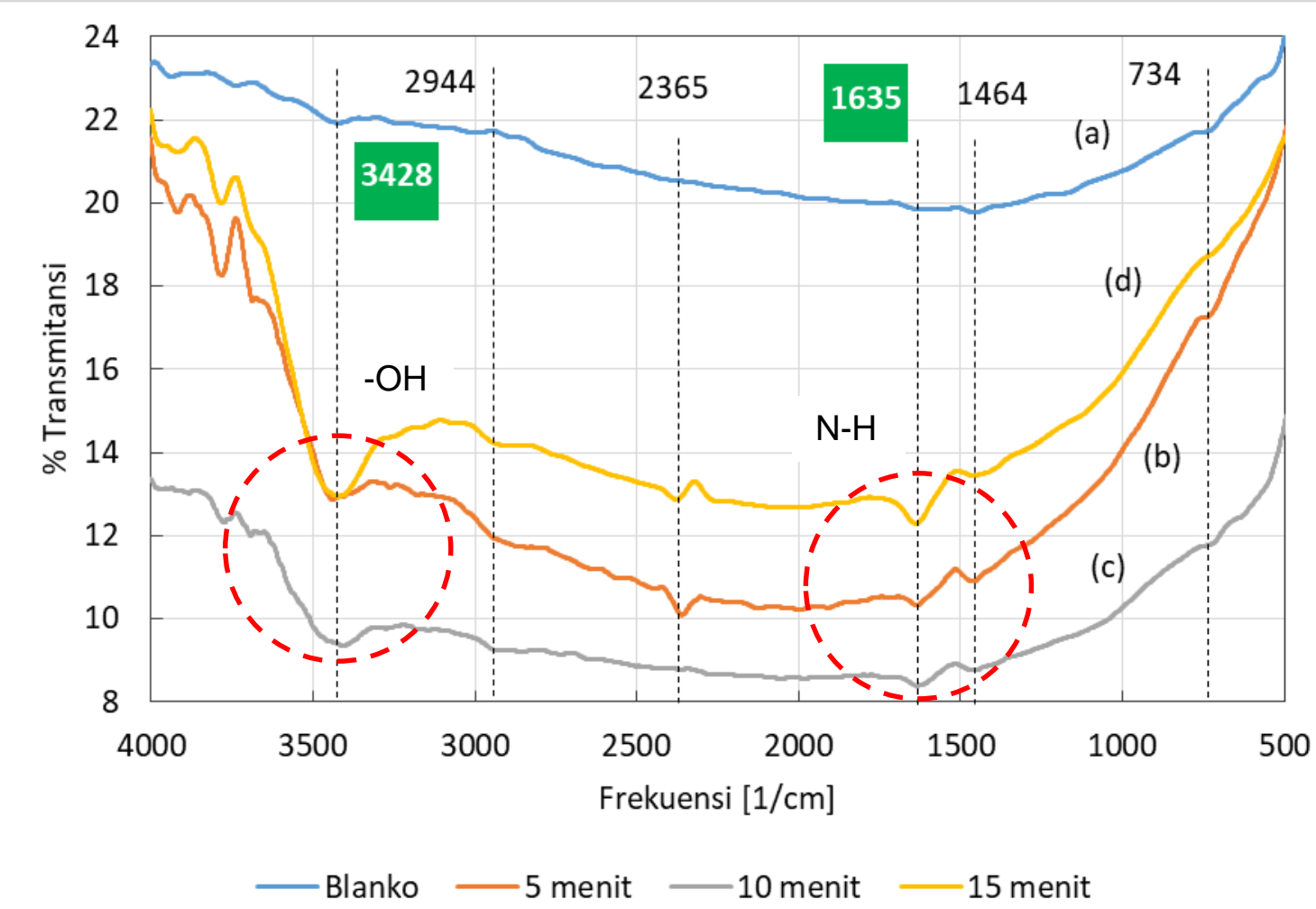

Gambar 8. Spektra FTIR dari jaring polietilena (a) sebelum iradiasi plasma dan sesudah iradiasi selama (b) 5, (c) 10 dan (d) 15 menit.

Satu hal yang menarik dan sebetulnya perlu dilakukan adalah analisa pembentukan dan kepadatan radikal permukaan pada polietilena setelah diiradiasi plasma. Di samping gugusgugus hidrofilik $-\mathrm{OH}$ dan $-\mathrm{NH}$, sebagaimana telah dijelaskan sebelumnya, radikal bebas permukaan yang terbentuk akibat abstraksi atom hidrogen pada rantai alkil $-\mathrm{CH}_{2}$ oleh plasma menjadi pusat inisiasi yang kuat untuk kopolimerisasi cangkok NIPAAm. Semakin lama waktu iradiasi tentunya akan semakin banyak pula radikal dan pusat-pusat reaksi yang terbentuk pada permukaan polietilena. Pendeteksian dan analisa kuantitatif radikal bebas permukaan dapat dilakukan dengan bantuan spektroskop ESPR (electron spin paramagnetic resonance) Pendeteksian dan analisa kuantitatif radikal bebas permukaan dapat dilakukan dengan bantuan ESPR (electron spin paramagnetic resonance) spektroskopi. Metode altermatif yang lebih mudah tersedia adalah mengguna-kan senyawa kimia penangkap radikal (radical scavenger), yaitu 2,2-difenil-1-pikrilhidrazil (DPPH). Namun demikian, keduanya terpaksa tidak dilakukan karena keterbatasan dan direncanakan untuk dipelajari pada studi lanjutan.

\section{Pencangkokan PNIPAAM}

Gambar 9 berikut di bawah ini memperlihatkan citra SEM permukaan polietilena yang sudah melalui proses aktifasi dengan plasma dan reaksi pencangkokan dengan NIPAAm. Jika dibandingkan dengan citra SEM polietilena pada Gambar 6 nampak jelas perbedaannya. Pada Gambar 9 dapat diamati dengan jelas ada semacam lapisan yang menutupi permukaan polietilena. Keberadaan lapisan tersebut nampak lebih jelas pada Gambar 9c-d yang memperlihatkan lapisan di dekat 
daerah retakan pada permukaan bahan.

Interaksi unsur-unsur plasma dengan permukaan substrat akan menghasilkan radikal bebas permukaan. Radikal tersebut selanjutnya dapat menginduksi reaksi pencangkokan polimer ${ }^{1}$ ataupun reaksi-reaksi kimia permukaan lainnya. Dengan strategi ini, polimerisasi NIPAAm menjadi PNIPAAm berlangsung sesudah inisiasi oleh radikal permukaan dan pencangkokan secara grafting from dan tumbuh melalui mekanisme polimerisasi radikal bebas. Gambar 10 memperlihatkan gambaran reaksi pencangkokan dan polimerisasi NIPAAm yang diyakini berlangsung pada permukaan jaring berbahan polietilen. Pada Gambar 10 dapat dilihat radikal bebas yang terbentuk oleh iradiasi plasma pada rantai polimer

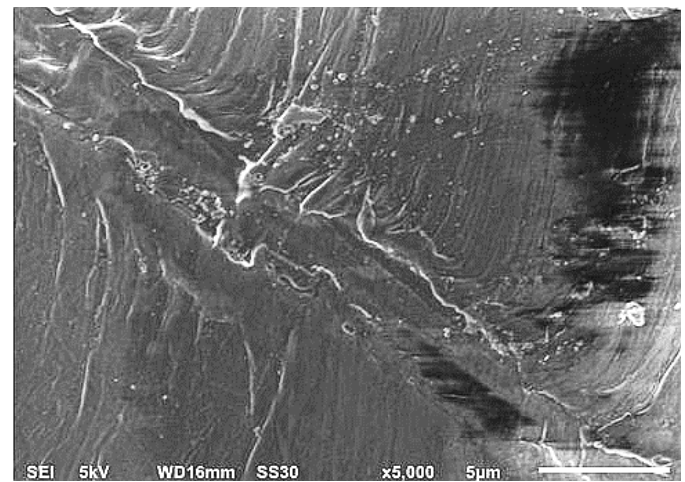

(a)

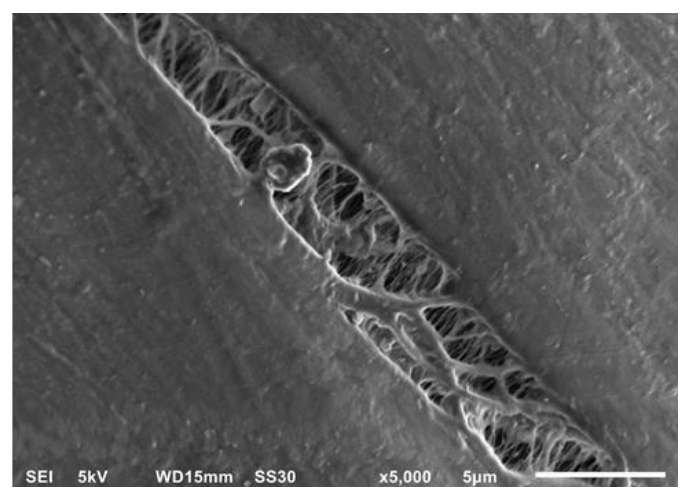

(c) polietilena (1) bereaksi dengan oksigen dan air yang terdapat di udara membentuk peroksida dan gugusgugus reaktif lain yang mengandung oksigen termasuk pula karboksilat. Hal tersebut sesuai dengan pengamatan hasil analisa FTIR terhadap jaring yang sudah diberi perlakuan plasma (Gambar 8). Pada pemanasan, peroksida tersebut terdekomposisi dan berubah menjadi radikal (2) yang menyediakan pusat reaksi bagi pencangkokan. Kopolimerisasi juga dapat berlangsung melalui reaksi antara radikal bebas permukaan pada polietilena dengan NIPAAm dan nampaknya inilah yang terjadi karena proses pencangkokan di sini hanya dilakukan dengan cara merendam sampel hasil iradiasi plasma selama 30 menit pada suhu kamar.

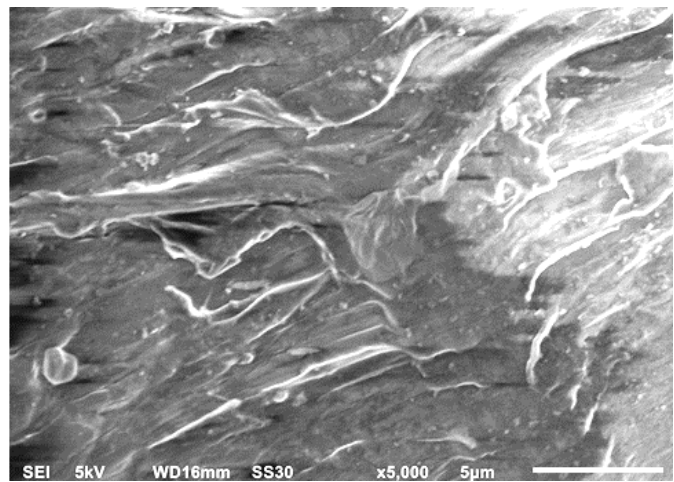

(b)

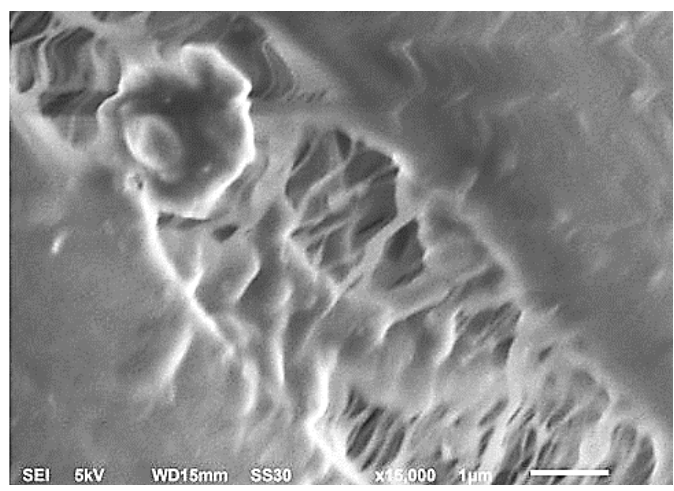

(d)

Gambar 9. Citra SEM permukaan polietilena yang telah diiradiasi plasma selama (a) 5 dan (b) 10 menit dan direaksikan dengan NIPAAm. Pembentukan lapisan dapat dilihat jelas pada sekitar daerah retakan (c) dan (d). 


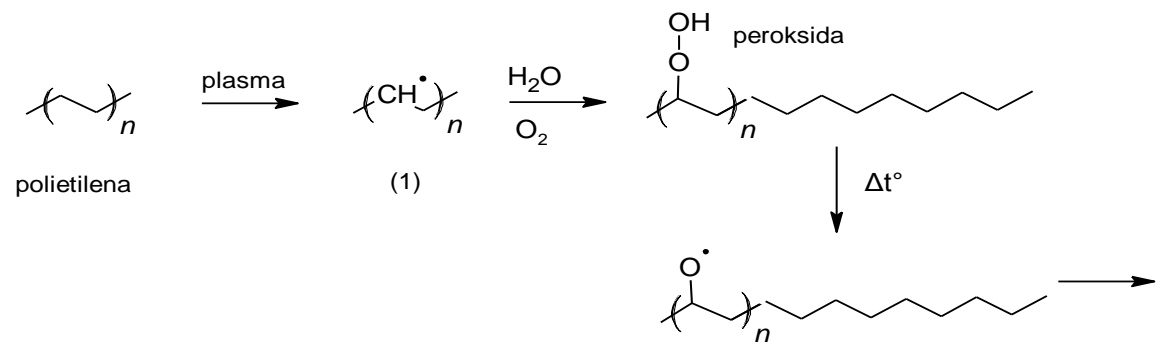

(2)

(1)

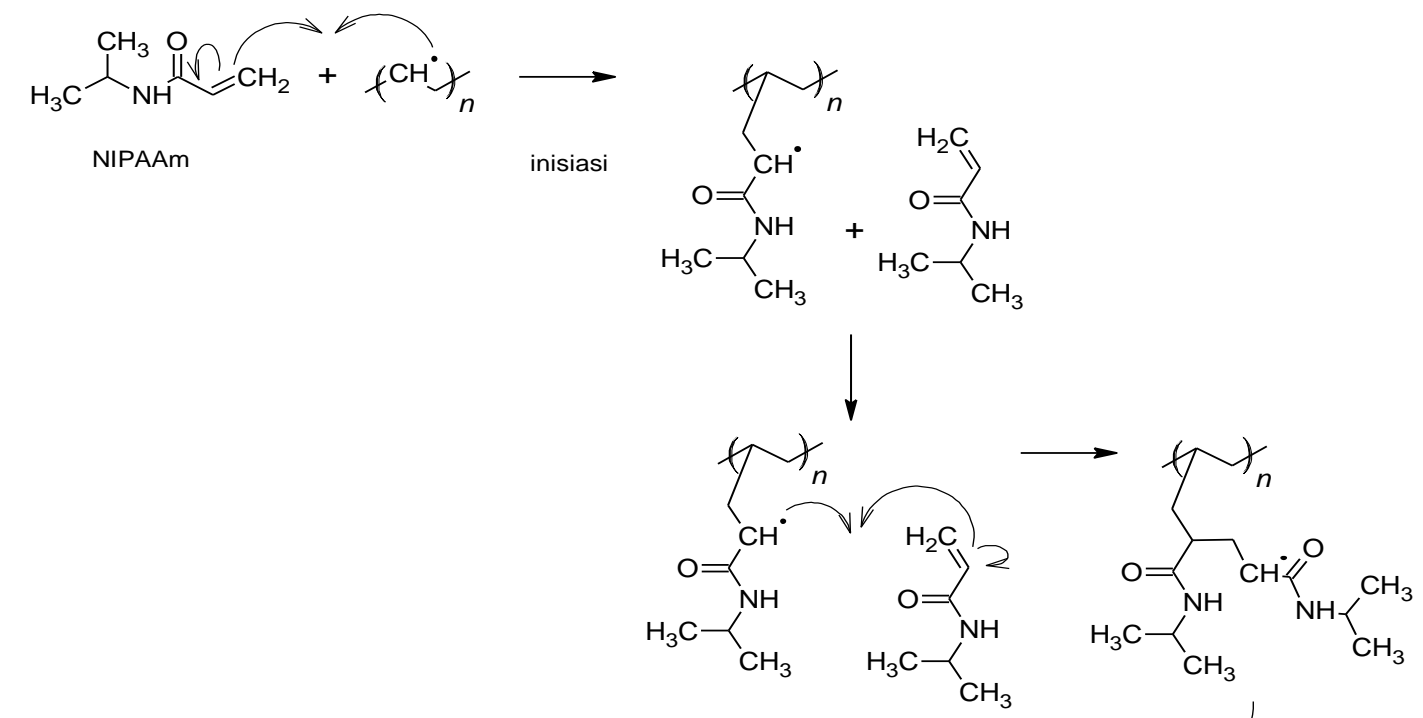

polietilena

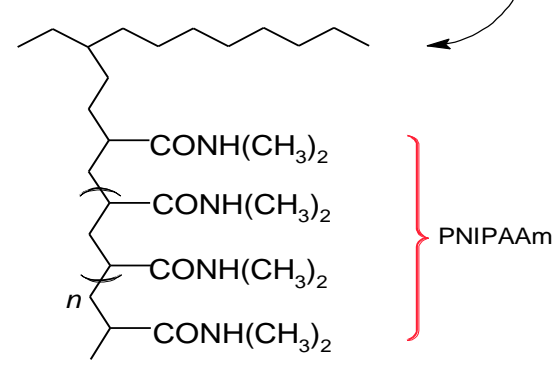

Gambar 10. Reaksi pencangkokan dan polimerisasi NIPAAm pada rantai alkil dari polietilena melalui iradiasi plasma.

Sebagaimana tampak pada Gambar 10, NIPAAm memiliki gugus $\mathrm{C}=\mathrm{O}, \mathrm{NH}$, dan gugus terminal $\mathrm{CH}_{3}$, sehingga keberhasilan pencangkokan NIPAAm dapat dideteksi dengan keberadaan gugus-gugus tersebut pada hasil analisa FTIR. Meskipun demikian, teknik analisa ini tidak dapat mengidentifikasi apakah telah terjadi polimerisasi sebagaimana digambarkan pada Gambar 10. Wang dan McCord ${ }^{1}$ dalam studinya mengenai pencangkokan NIPAAm pada nilon melaporkan adanya puncak-puncak baru pada spektra FTIR kain nilon yang sudah direaksikan dengan NIPAAm, yaitu pada frekuensi $1540 \mathrm{~cm}^{-1}$ (regangan $\mathrm{NH}$ amida sekunder), 1650 $\mathrm{cm}^{-1}$ (regangan amida sekunder $\mathrm{C}=\mathrm{O}$ ), $2970 \mathrm{~cm}^{-1}$ (regangan asimetris $-\mathrm{CH}_{3}$ ), dan $3301 \mathrm{~cm}^{-1}$ (regangan $\mathrm{NH}$ amida sekunder). 


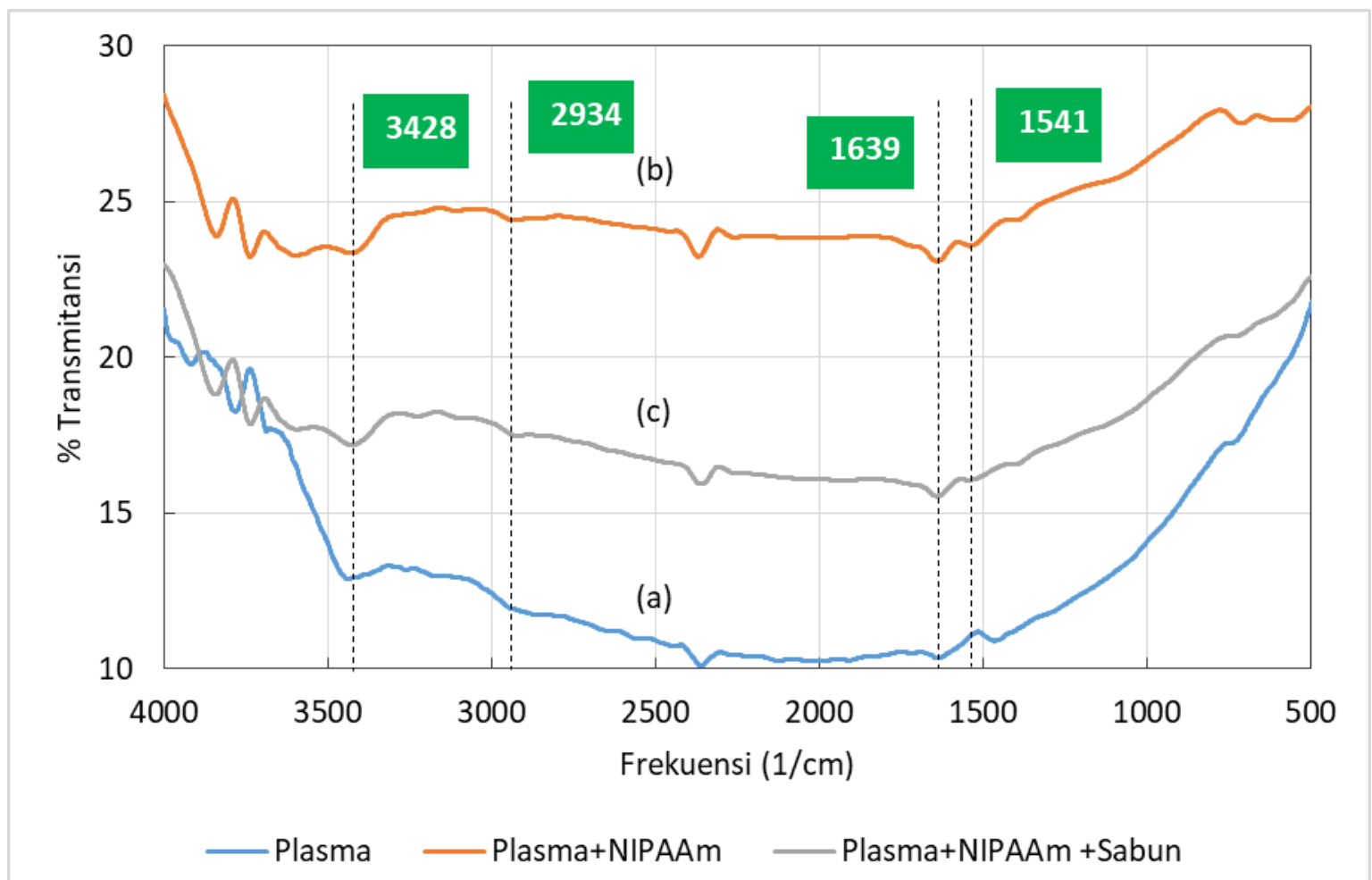

Gambar 11. Spektra polietlena hasil perlakuan dengan (a) plasma selama 5 menit, dan diikuti dengan perendaman dalam NIPAAm selama 30 menit (b) tanpa pencucian dan (c) dengan pencucian.

Gambar 11 memperlihatkan spektra hasil FTIR jaring polietilena yang sudah diiradiasi plasma selama 5 menit dan direaksikan dengan NIPAAm. Dapat dilihat perlakuan dengan NIPAAm memunculkan dua puncak baru pada $1541 \mathrm{~cm}^{-1}$ yang mengindikasikan regangan $\mathrm{NH}$ amida sekunder, 1639 $\mathrm{cm}^{-1}$ yang menunjukkan regangan amida sekunder $\mathrm{C}=\mathrm{O}, 2934 \mathrm{~cm}^{-1}$ yang mengindikasikan regangan asimetris $\mathrm{CH}_{3}$, dan $3428 \mathrm{~cm}^{-1}$ yang menunjukkan adanya regangan $\mathrm{NH}$ amida sekunder. Puncak-puncak baru tersebut dapat diamati dengan jelas pada semua spektra hasil pencangkokan dengan NIPAAm sebelum dan sesudah pencucian dengan air maupun detergen. Hal tersebut menunjukkan bahwa NIPAAm memang telah berikatan kimia dan tercangkok dengan baik pada permukaan jaring polietilena. Pengamatan yang sama juga dapat dilihat terutama pada hasil perlakuan dengan plasma selama 15 menit
(Gambar 12). Pada Gambar 12, puncak serapan pada $1639 \mathrm{~cm}^{-1}$ yang ada pada spektra (a) tidak ditemukan pada spektra (b) dan (c) dan sebagai gantinya muncul puncak baru pada $1672 \mathrm{~cm}^{-1}$. Di samping itu puncak serapan pada $3438 \mathrm{~cm}^{-1}$ yang semula ada pada spektra (a) dan merupakan indikasi keberadaan - $\mathrm{OH}$ dan/atau $-\mathrm{NH}$ juga tidak ditemukan pada spektra (b) dan (c). Hal tersebut mengindikasikan dengan jelas kemungkinan sangat besar bahwa gugus amina dan hidroksil telah menjadi pusat reaksi kopolimerisasi dengan NIPAAm karena puncak-puncak serapannya hilang dan berganti dengan puncak serapan khas NIPAAm, yaitu $\mathrm{C}=\mathrm{O}$ pada $1672 \mathrm{~cm}^{-1}$. Sebelumnya, yaitu pada Gambar 11, hal ini sulit untuk disimpulkan karena keberadaan NIPAAm dengan puncak serapan $1639 \mathrm{~cm}^{-1}$ bertumpang tindih dengan bending $\mathrm{N}-\mathrm{H}$ pada puncak serapan yang sama. Perlu diperhatikan pula bahwa puncak serapan pada 3438 
$\mathrm{cm}^{-1}$ yang menjadi indikasi keberadaan $\mathrm{N}-\mathrm{H}$ (dan/atau O-H) pada polietilena hasil perlakuan plasma (spektra a) juga hilang dan tidak didapati pada spektra hasil perendaman dalam NIPAAm (b dan c) serta berganti menjadi minima.
Hal tersebut memperjelas dugaan mengenai keterlibatan gugus-gugus baru $-\mathrm{OH}$ dan $-\mathrm{NH}$ dalam proses kopolimerisasi NIPAAm pada polietilena dengan plasma.

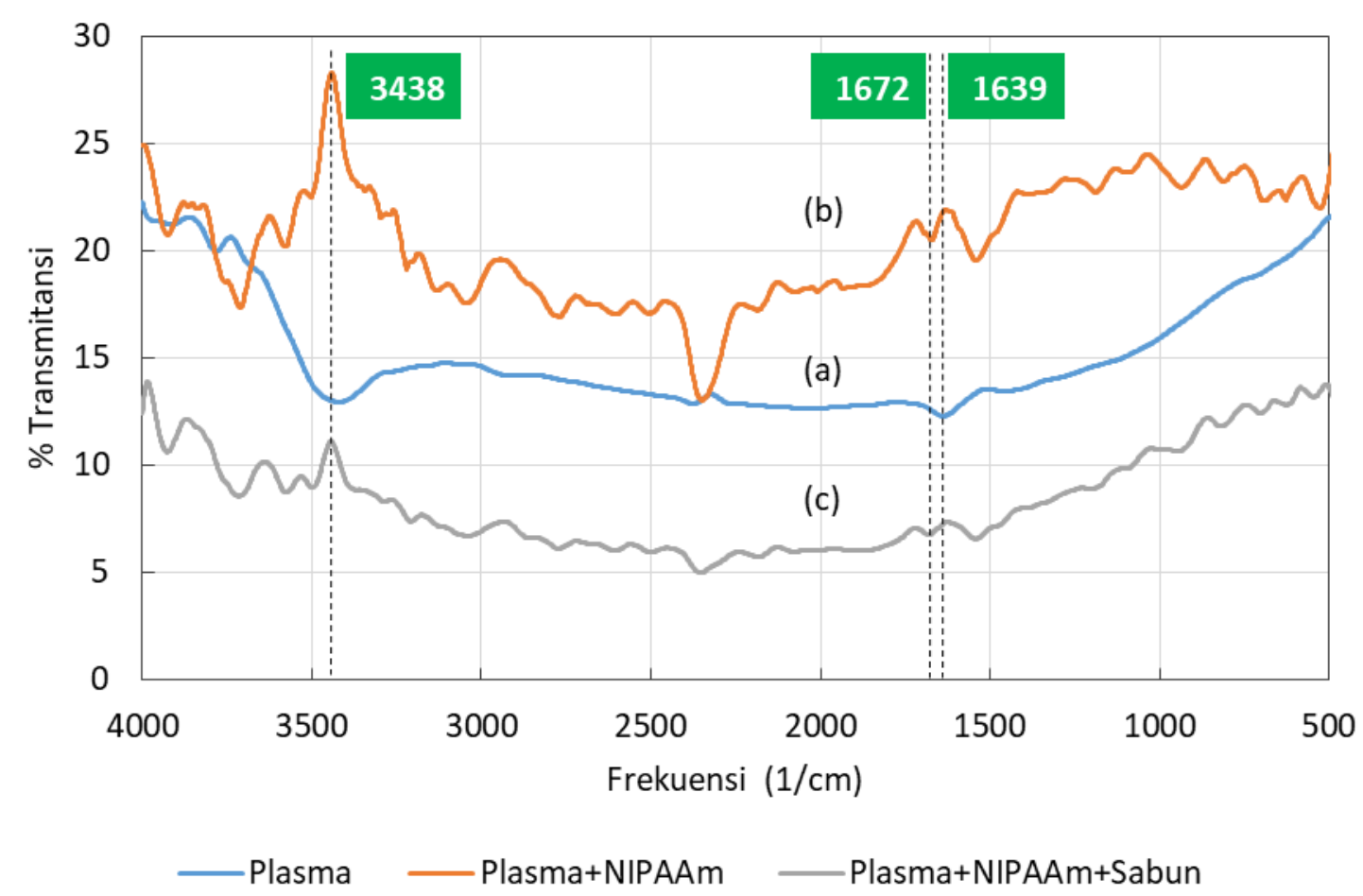

Gambar 12. Spektra polietlena hasil perlakuan dengan (a) plasma selama 15 menit, dan diikuti dengan perendaman dalam NIPAAm selama 30 menit (b) tanpa pencucian dan (c) dengan pencucian.

Berkaitan dengan hal tersebut, menarik pula untuk dicatat bahwa puncak serapan $\mathrm{O}-\mathrm{H}$ dan/atau $\mathrm{N}-\mathrm{H}$ pada Gambar 11 masih dapat teramati pada spektra hasil perendaman dengan NIPAAm (b dan c), sedangkan pada Gambar 12 puncak serapan yang mewakili keberadaan $\mathrm{O}-\mathrm{H}$ maupun $\mathrm{N}-\mathrm{H}$ sudah tidak ada. Dapat disimpulkan bahwa pencangkokan NIPAAm pada iradiasi plasma 15 menit telah berlangsung lebih ekstensif daripada iradiasi plasma 5 menit sehingga jumlah NIPAAm yang berhasil dicangkokkan pun lebih banyak di mana seluruh bagian permukaan polietilena tertutup oleh PNIPAAm. Kesimpulan ini dapat dikonfirmasi dengan data kadar pencangkokan (grafting yield/GY) melalui perhitungan penambahan berat.

Kadar pencangkokan (GY) dapat ditentukan dengan membandingkan berat sebelum dan sesudah pencangkokan pada sampel yang sudah dicuci. Hasil perhitungan kadar pencangkokan pada jaring polietilena yang diradiasi plasma selama 5 menit memperlihatkan kadar pencangkokan sebesar $2,83 \%$ atau $0,1750 \mathrm{mg} / \mathrm{cm}^{2}$, sedangkan pada iradiasi plasma dengan waktu 10 menit dihasilkan GY sebesar $0,3000 \mathrm{mg} / \mathrm{cm}^{2}$ atau sebesar $4,82 \%$, kemudian pada waktu iradiasi plasma selama 15 menit diperoleh GY sebesar $0,3250 \mathrm{mg} / \mathrm{cm}^{2}$ atau $5,37 \%$ 
(Gambar 13). Hasil tersebut sejalan dengan kesimpulan pada paragraf sebelumnya dan pemikiran bahwa semakin lama waktu iradiasi plasma semakin banyak radikal permukaan yang terbentuk pada jaring polietilena, sehingga semakin banyak pula NIPAAm yang dapat dicangkokkan dan terepre-sentasikan pada semakin besarnya kadar pencangkokan (GY).

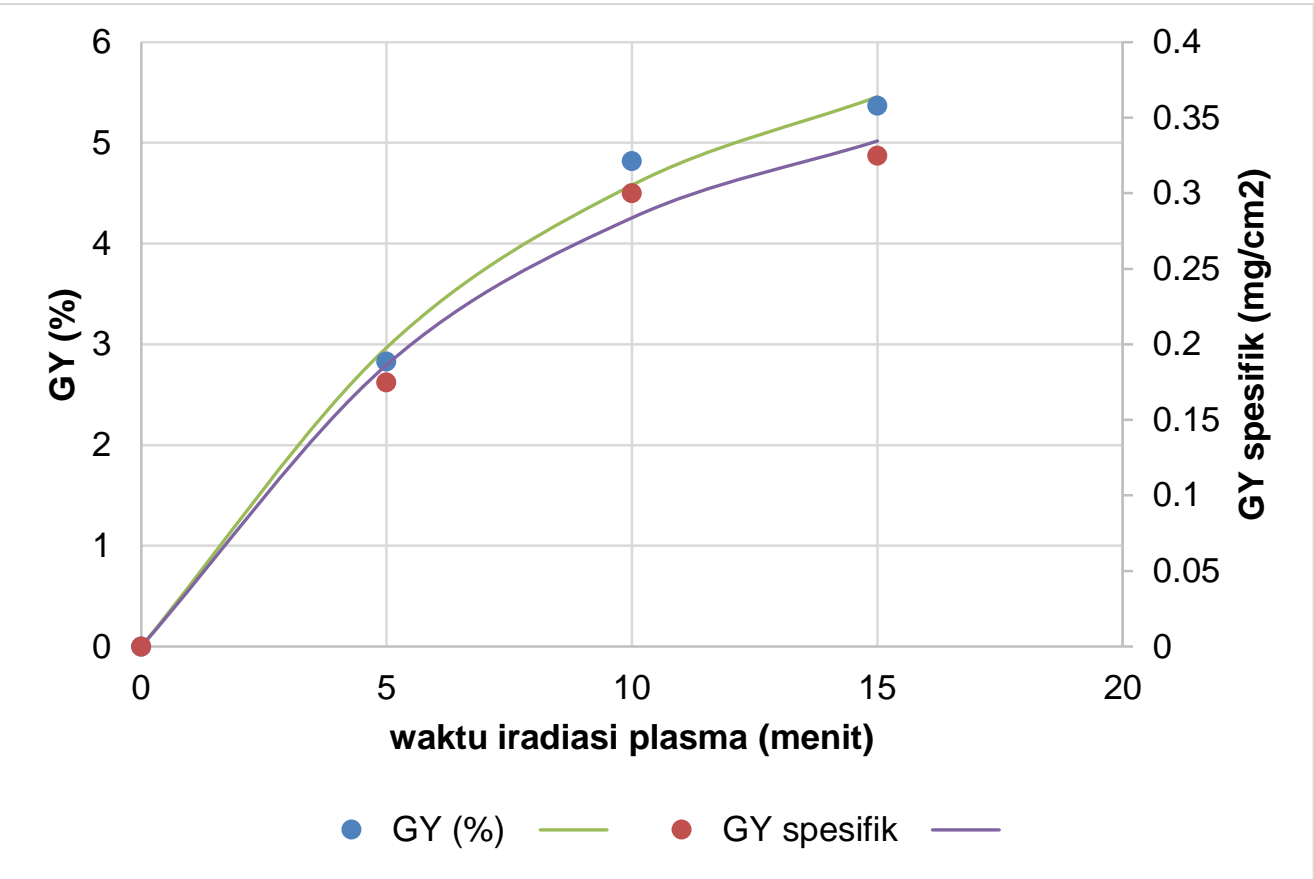

Gambar 13. Kadar pencangkokan NIPAAm pada jaring polietilena raschel sesuai dengan waktu iradiasi plasma.

Pada Gambar 13 dapat diamati bahwa kenaikan kadar pencangkokan mengikuti suatu tren perilaku eksponensial dengan persamaan umum:

$$
G Y=a\left(1-e^{-b t}\right)
$$

di mana $t$ adalah waktu iradiasi plasma, sedangkan $a$ dan $b$ adalah konstanta yang berhubungan dengan jenis bahan dan parameter plasma. Kurva yang melandai pada waktu iradiasi yang lebih lama menunjukkan bahwa penambahan radikal permukaan sebagai pusat-pusat reaksi semakin berkurang seiring dengan bertambah banyaknya radikal yang terbentuk. Hal tersebut sangat wajar jika diingat bahwa permukaan yang terpopulasi oleh radikal semakin luas sehingga permukaan yang tersisa dan masih tersedia untuk pembentukan radikal pun berkurang hingga sampai pada satu titik dimana perlakuan plasma yang lebih lama tidak lagi menghasilkan pembentukan radikal permukaan.

\section{KESIMPULAN}

Pada penelitian ini terbukti bahwa iradiasi jaring raschel dari polietilena oleh plasma dapat mengaktivasi permukaannya dengan membentuk radikal bebas. Radikal bebas yang terbentuk oleh iradiasi plasma pada rantai polimer polietilena bereaksi dengan oksigen dan nitrogen yang terdapat di udara membentuk gugusgugus reaktif yang mengandung oksigen dan nitrogen. NIPAAm telah berhasil dicangkokkan pada polietilena sesuai dengan hasil pengamatan dengan SEM dan analisa gugus-gugus 
fungsional kimia NIPAAm dengan FTIR serta pertambahan berat. Semakin lama waktu radiasi plasma semakin banyak NIPAAm yang berhasil dicangkokkan pada bahan mengikuti suatu model pertumbuhan dengan pengurangan laju secara eksponensial dan ditentukan oleh ketersediaan permukaan untuk diaktifasi. Untuk studi selanjutnya akan dipelajari pengaruh parameter proses plasma terhadap pembentukan dan kepadatan radikal bebas permukaan pada bahan (radical density) dan juga pertumbuhan PNIPAAm (ketebalan lapisan polimer).

\section{UCAPAN TERIMA KASIH}

Terima kasih kepada Politeknik STTT Bandung yang telah membiayai penelitian ini melalui program Penelitian Dosen Tahun Anggaran 2020 yang dikelola oleh Unit Penelitian dan Pengabdian kepada Masyarakat. Hasil penelitian telah dipresentasikan dalam seminar Hasil Penelitian Dosen Tahun 2020. 


\section{DAFTAR PUSTAKA}

1. Wang, X. \& McCord, M. G. Grafting of poly(N-isopropylacrylamide) onto nylon and polystyrene surfaces by atmos-pheric plasma treatment followed with free radical graft copolymerization. Journal of Applied Polymer Science 104, 36143621 (2007).

2. Lubben, J. F. et al. Functionalization of Textiles with Themoresponsive Polymers. Journal of Fashion Technology \& Textile Engineering s4, (2018).

3. Teotia, A. K., Sami, H. \& Kumar, A. Thermo-responsive polymers: Struc-ture and design of smart materials. in Switchable and Responsive Surfaces and Materials for Biomedical Applica-tions 3-43 (Elsevier Inc., 2015). doi:10.1016/B978-085709-713-2.00001-8.

4. Yang, $\mathrm{H}$. et al. Temperature-Triggered Collection and Release of Water from Fogs by a Sponge-Like Cotton Fabric. Advanced Materials 25, 1150-1154 (2013).

5. Wei, M., Gao, Y., Li, X. \& Serpe, M. J. Stimuli-responsive polymers and their applications. Polymer Chemistry vol. 8 127-143 (2017).

6. Rajaram, M., Heng, X., Oza, M. \& Luo, C. Enhancement of fog-collection efficiency of a Raschel mesh using surface coatings and local geometric changes. Colloids and Surfaces A: Physicochemical and Engineering As-pects 508, 218-229 (2016).

7. Azad, Md. A. K. Fog Collection on Plant Surfaces and Biomimetic Appli-cations. (Universitäts- und Landesbib-liothek Bonn, 2016).

8. Ramadhan, A. F. \& Hariyono, D. Pengaruh Pemberian Naungan Ter-hadap Pertumbuhan dan Hasil Pada Tiga Varietas Tanaman Stroberi (Fragaria chiloensis L.). Jurnal Produksi Tanaman 7, (2019).

9. Lanzalaco, S., Turon, P., Weis, C., Alemán, C. \& Armelin, E. The mecha-nism of adhesion and graft polymeriza-tion of a PNIPAAm thermoresponsive hydrogel to polypropylene meshes. Soft Matter 15, 3432-3442 (2019).

10. Wang, X. L., Huang, J., Chen, X. Z. \& Yu, X. H. Graft polymerization of Nisopropylacrylamide into a microporous polyethylene membrane by the plasma method: Technique and morphology. Desalination 146, 337-343 (2002).

11. Polymer Data Handbook. (Oxford Uni-versity Press, 2009). 